\title{
The P2X7 ion channel is dispensable for energy and metabolic homeostasis of white and brown adipose tissues
}

\author{
$\operatorname{Tian}_{\operatorname{Tian}^{1}}{ }^{1}$ Markus Heine ${ }^{1} \cdot$ loannis Evangelakos ${ }^{1} \cdot$ Michelle Y. Jaeckstein ${ }^{1} \cdot$ Nicola Schaltenberg $^{1} \cdot$ Tobias Stähler $^{2}$. \\ Friedrich Koch-Nolte ${ }^{2} \cdot$ Manju Kumari ${ }^{1} \cdot$ Joerg Heeren ${ }^{1}$ (D)
}

Received: 6 July 2020 / Accepted: 20 September 2020 / Published online: 6 October 2020

(C) The Author(s) 2020

\begin{abstract}
Several studies suggest a role of extracellular adenine nucleotides in regulating adipose tissue functions via the purinergic signaling network. Metabolic studies in mice with global deletion of the purinergic receptor P2X7 on the C57BL/6 background indicate that this receptor has only a minor role in adipose tissue for diet-induced inflammation or cold-triggered thermogenesis. However, recent data show that a polymorphism (P451L) present in C57BL/6 mice attenuates P2X7 receptor function, whereas $\mathrm{BALB} / \mathrm{c}$ mice express the fully functional $\mathrm{P} 451$ allele. To determine the potential role of $P 2 r x 7$ under metabolic and thermogenic stress conditions, we performed comparative studies using male $P 2 r \times 7$ knockout $(\mathrm{KO})$ and respective wild-type controls on both $\mathrm{BALB} / \mathrm{c}$ and C57BL/6 backgrounds. Our data show that adipose $P 2 r x 7 \mathrm{mRNA}$ levels are increased in obese mice. Moreover, $P 2 r x 7$ deficiency results in reduced levels of circulating CCL2 and IL6 with a moderate effect on gene expression of proinflammatory markers in white adipose tissue and liver of BALB/c and C57BL/6 mice. However, P2X7 expression does not alter body weight, insulin resistance, and hyperglycemia associated with high-fat diet feeding on both genetic backgrounds. Furthermore, deficiency of $P 2 r x 7$ is dispensable for energy expenditure at thermoneutral and acute cold exposure conditions. In summary, these data show that - apart from a moderate effect on inflammatory cytokines-P2X7 plays only a minor role in inflammatory and thermogenic effects of white and brown adipose tissue even on the BALB/c background.
\end{abstract}

Keywords Purinergic signaling $\cdot$ Adipose tissue $\cdot$ P2X7 ion channel $\cdot$ Energy metabolism $\cdot$ Obesity

\section{Introduction}

Adipose tissue is a complex organ with an important role in endocrine, metabolic, and immune regulatory processes. In mammals, there are two types of adipose tissues: white adipose tissue (WAT) composed of white adipocytes that stores energy in the form of triglycerides and brown adipose tissue

Electronic supplementary material The online version of this article (https://doi.org/10.1007/s11302-020-09738-7) contains supplementary material, which is available to authorized users.

Manju Kumari

mkumari@uke.de

Joerg Heeren

heeren@uke.de

1 Department of Biochemistry and Molecular Cell Biology, University Medical Center Hamburg-Eppendorf, 20246 Hamburg, Germany

2 Institute of Immunology, University Medical Center Hamburg-Eppendorf, 20246 Hamburg, Germany
(BAT), characterized by uncoupling protein 1 (UCP1) expressing brown adipocytes which combusts energy-rich nutrients for heat production [1-3]. The balanced function of the two types of adipose tissues plays a major role in maintaining whole body energy homeostasis. Accordingly, adipose tissue dysfunction is closely related to metabolic disorders such as obesity, insulin resistance, and hyperglycemia $[4,5]$. It has been established that chronic, subclinical inflammation in WAT depots is a key player in the development of insulin resistance in obesity [6]. Strong infiltration of immune cells, especially macrophages, into WAT takes place upon exposure to an obesogenic high-fat diet which is associated with increased production of cytokines and chemokines $[7,8]$. This is correlated with local expression of genes for inflammatory mediators such as Tnf, Il6, and Ccl2 [9]. Adipose tissue mRNA as well as circulating CCL2 and IL6 levels correlate positively with the degree of corpulence and insulin resistance in obese mice and humans [9-12].

Recent studies have indicated that extracellular adenosine 5-triphosphate (ATP) is involved in the regulation of tissue 
inflammation via a purinergic signaling network, which involves the release of ATP, ectoenzymes hydrolyzing ATP to adenosine such as CD39 (ectonucleoside triphosphate diphosphohydrolase-1) and CD73 (ecto-5'-nucleotidase) [13, 14]. Importantly, extracellular ATP activates purinergic receptors of the P2X and P2Y families. Unlike the G proteincoupled $\mathrm{P} 2 \mathrm{Y}$ receptors, $\mathrm{P} 2 \mathrm{X}$ receptors are ligand-gated ion channels. Of the 7 members of $\mathrm{P} 2 \mathrm{X}$ receptor family, $\mathrm{P} 2 \mathrm{X} 7$ has been studied intensively due to its unique ability to activate the inflammasome [15]. Increased levels of extracellular ATP activate P2X7, leading to rapid $\mathrm{K}^{+}$efflux, activation of the caspase- 1 containing inflammasome NLRP3, and pore formation by pannexins and gasdermin $\mathrm{D}$ [16]. The activation of P2X7 is also associated with other cell-specific signaling pathways involved in inflammation, such as inflammatory cytokine production, reactive oxygen and nitrogen species formation, and protease activation [17-19].

The murine $P 2 r x 7$ gene has a functional single nucleotide polymorphism (SNP) at position 451 named as P451L [20]. Compared with the wild-type allele $451 \mathrm{P}$, the $451 \mathrm{~L}$ allele is reported to have lower sensitivity to ATP in T cells [20]. Further studies indicate that P451L SNP is associated with $P 2 r x 7$ induced functions including pore formation, cell death, and intracellular $\mathrm{Ca}^{2+}$ waves $[21,22]$. The $P 2 r x 7$ alleles P451 and $451 \mathrm{~L}$ are differently distributed in mouse strains, whereas $\mathrm{BALB} / \mathrm{c}$ mice encode the full-functional P451 allele while C57BL/6 mice carry the 451L allele [20, 23, 24].

The aim of this study was to determine the expression of purinergic receptors $(P 2 r x 4, P 2 r \times 5, P 2 r x 7)$ in adipose tissue of obese mice and in isolated adipocytes, endothelial cells, and tissue-resident macrophages of adipose tissue under normal and cold adaptation housing condition. Moreover, we investigated the role of $\mathrm{P} 2 \mathrm{X} 7$ in diet-induced obesity, adipose tissue inflammation, and energy expenditure on BALB/c and C57BL/6 genetic background. The results of our metabolic studies show that despite reduced systemic inflammation, P2rx 7 deficiency does not alter diet-induced obesity, insulin resistance, and hyperglycemia associated with high-fat diet (HFD) feeding or thermogenic responses in BALB/c and C57BL/6 backgrounds.

\section{Materials and methods}

Experimental mice and diet study $P 2 r x 7 \mathrm{KO}$ mice [25] were backcrossed to $\mathrm{C} 57 \mathrm{BL} / 6$ and $\mathrm{BALB} / \mathrm{c}$ mice for 16 generations and were maintained under specific pathogen-free conditions at the central animal facility of the UKE. All experiments were performed according to state guidelines with approval of the local institutional regulatory committee. We used agematched male BALB/c and C57BL/6J wild-type mice and P2rx7 KO mice. Mice were maintained on a standard chow diet $(19.10 \%$ protein, $4 \%$ fat, $6 \%$ fiber, from Altromin
Spezialfutter GmbH\&Co, Germany) under a regular 12-h light/12-h dark cycle at $22{ }^{\circ} \mathrm{C}$ temperature. High-fat diet experiments in BALB/c and C57BL/6J wild-type and P2rx $7 \mathrm{KO}$ mice were performed by feeding 6-week-old male mice a high-fat diet (20\% protein, $35.6 \%$ fat, $0.3 \%$ fiber, $23.2 \%$ sugar, from ssniff Spezialitäten $\mathrm{GmbH}$, Germany) for 16 weeks in a humidity-controlled climate chamber at thermoneutral $\left(30^{\circ} \mathrm{C}\right)$ or room temperature $\left(22^{\circ} \mathrm{C}\right)$ conditions. Body weight was measured weekly. Whole body composition was measured by echoMRI (EchoMRITM, USA). At the end of experiments, mice were sacrificed by cervical dislocation, and harvested tissues were either formalin-fixed for histology analyses or snap frozen in liquid nitrogen for quantitative PCR and Western blot analyses. Frozen tissues were stored at $-80^{\circ} \mathrm{C}$.

Energy expenditure measurement Metabolic rate was measured by indirect calorimetry in metabolic cages (TSE system GmbH, Germany) as described [26]. The system was operated according to the manufactures guidelines. All mice were acclimatized to monitoring cages for $48 \mathrm{~h}$ prior to the beginning of physiological parameters recording. In this climatecontrolled indirect calorimetry setup, $\mathrm{O}_{2}$ consumption, $\mathrm{CO}_{2}$ production, food and drink intake, as well as activity were monitored. Mice were housed under 12 to 12 -h light/dark cycle. In order to determine thermogenic capacity in $P 2 r x 7$ $\mathrm{KO}$ and wild-type mice, the temperature was gradually decreased by $4-5^{\circ} \mathrm{C}$ (from 3 to $6^{\circ} \mathrm{C}$ ) at 7 a.m. each day.

Glucose tolerance test To determine glucose tolerance, mice were fasted for $6 \mathrm{~h}$ followed by an intraperitoneal injection of glucose (Sigma) at $1 \mathrm{~g} / \mathrm{kg}$ body weight. Blood samples were collected at 0, 15, 30, 60, 90, and $120 \mathrm{~min}$. Glucose levels were measured using Accuchek Aviva (Roche).

Plasma and liver parameters Plasma and liver cholesterol and triglyceride levels were quantified using commercial kits (Roche) that were adapted to 96-well microtiter plates according to manufacturer's instructions. Ultra-Sensitive Mouse Insulin ELISA kit (Crystal Chem) was used for the quantitative determination of insulin in mouse plasma.

Tissue histology Adipose tissues were fixed in $3.7 \%$ formalin for $24 \mathrm{~h}$, embedded in paraffin, and sectioned by the Leica RM 2245 microtome for hematoxylin and eosin (H\&E) staining. For immunohistochemistry, sections were subjected to antigen retrieval in citrate buffer (pH 6). After blocking with 3\% BSA for $1 \mathrm{~h}$ at room temperature, primary rat monoclonal anti-MAC-2 antibody was diluted 1:250 in 3\% BSA and incubated over night at $4{ }^{\circ} \mathrm{C}$. HRP-anti-rat secondary antibody was diluted 1:250 and incubated for $1 \mathrm{~h}$ at room temperature. High resolution digital images were taken using the Nikon eclipse Ti Microscope. 
Isolation of adipocytes, macrophages, and endothelial cells from adipose tissue After collagenase (Sigma, USA) digestion of WAT and BAT harvested from 4 mice, large adipocytes were separated by low speed centrifugation. Next, magnetic separation was performed according to the manufacturer's instructions using an autoMACS pro Separator (Miltenyi Biotec GmbH, Germany). The cell pellet was resuspended in $900 \mu \mathrm{l}$ MACS sorting buffer and incubated with $100 \mu \mathrm{l} \mathrm{Cd} 11 \mathrm{~b}$ MicroBeads (MiltenyiBiotec GmbH, Germany) per $10^{7}$ total cells at $4{ }^{\circ} \mathrm{C}$ for $15 \mathrm{~min}$. After centrifugation, the cell pellet was re-suspended and cell suspension was applied on LS columns (MiltenyiBiotec GmbH, Germany). The magnetically labeled $\mathrm{Cd} 11 \mathrm{~b}+$ macrophage cell fraction was collected from LS columns. The flow through fraction was incubated with $\mathrm{Cd} 31$ MicroBeads (MiltenyiBiotec $\mathrm{GmbH}$, Germany) and applied on LS columns to collect $\mathrm{Cd} 31+$ endothelial cells. The last flow through fraction was obtained as adipocytes.

RNA isolation and qRT-PCR qPCR analysis was performed as described previously [27]. Briefly, RNA was extracted using the Nucleo Spin RNA® (Macherey-Nagel ${ }^{\mathrm{TM}}$, Germany) according to the manufacturer's protocol. RNA was quantified using NanoDrop (Thermo Scientific, Wilmington, DE) and converted to cDNA using SuperScript III Reverse Transcriptase (Invitrogen). Real-time qPCR was performed on a 7900HT Sequence Detection System (Applied Biosystems, USA) using TaqMan Assay-on-Demand primer sets (Applied Biosystems) (Tbp:Mm00446973_m, Cd39:Mm00515447_m1, Cd73:Mm00501910_m1, P2rx4:Mm00501787_m1, P2rx7:Mm01199500_m1, P2rx5:Mm00473677_m1, Adipoq:Mm00456425_m1, Gpihbp 1:Mm01205849_g1, Emr1:Mm00802530_m1, Ucp 1:Mm00494069_m1, Arg1:Mm00475988_m1, Tnf:Mm00443258_m1, Illb:Mm00434228_m1, Il6:Mm00446190_m1, Ccl2:Mm00441242_m1, Nlrp3:Mm00840904_m1, Cd4:Mm00442754_m1, Cd8b1:Mm00438116_m1, Acta2: Mm01546133_m1, Colla1:Mm00801666_g1, Timp1:Mm00441818_m1, Tgfb1: Mm00441724_m1, Mmp 12:Mm00500554_m1, Mmp13:Mm00439491_m1, Trem2:Mm00451744_m1). Cycling parameters were as follows: 1 cycle of $95{ }^{\circ} \mathrm{C}$ for $10 \mathrm{~m}, 40$ cycles of $95^{\circ} \mathrm{C}$ for $15 \mathrm{~s}$ then $60^{\circ} \mathrm{C}$ for $60 \mathrm{~s}$, followed by melt curve analysis. Cycle thresholds ( $\mathrm{Ct}$ values) were normalized to those of the Tbp housekeeping gene.

Protein extraction and Western blotting Total lysates were prepared by homogenizing various tissues in RIPA buffer supplemented with protease inhibitors (Roche) and phosphatase inhibitors (Sigma). Protein samples ( $25 \mu \mathrm{g}$ per lane) were separated by SDS-PAGE. Blots were blocked for $2 \mathrm{~h}$ in PanReac Blocking buffer (AppliChem), incubated for $1 \mathrm{~h}$ with appropriate primary antibody and $2 \mathrm{~h}$ with HRP-conjugated secondary antibody. Polyclonal rabbit antibodies directed against the $\mathrm{C}$-terminal peptides of $\mathrm{P} 2 \mathrm{X} 4$ and $\mathrm{P} 2 \mathrm{X} 7$ were from Abcam (Cat. No. ab243734, Cat. No. ab229453). The P2X7 antibody detected two bands at around $75 \mathrm{kDa}$ in BAT of $\mathrm{Balb} / \mathrm{c}$ mice. The upper band was also detectable in knockout mice, indicating that as a non-specific cross-reactivity of the antibody. P2X5 rabbit polyclonal antibody was purchased from Thermo Fisher (Cat. No. PA5-41079) and the loading control $\gamma$-tubulin rabbit monoclonal antibody from Abcam (Cat. No. ab179503). The secondary antibody, goat-antirabbit IgG horseradish peroxidase (HRP), was purchased from Bio-Rad. Detection was performed on Amersham Imager600 using luminol and para-hydroxycoumarinic acid-based chemiluminescence substrate.

Statistical analysis Results are expressed as mean \pm SEM. Comparisons between groups were made using either unpaired, two-tailed Student's $t$ test of the SPSS software for two-group comparisons or the two-way ANOVA test with Bonferroni post-tests of the PRISM software for multigroup comparisons. $P<0.05$ was considered statistically significant.

\section{Results}

\section{Gene expression analysis of $\mathrm{P} 2 \mathrm{X}$ receptors and nucleotide-metabolizing enzymes in WAT and BAT of lean, DIO, and ob/ob mice}

To assess the effect of nutritional state on expression of enzymes and receptors involved in purinergic signaling, we performed qPCR analyses of WAT and BAT isolated from lean and obese mice. Obesity is well-known to result in infiltration of pro-inflammatory macrophages [8]. In line, we detected increased expression of Emrl in WAT of both dietary (dietinduced obesity: DIO) and genetic (ob/ob) models of obesity (Fig. 1a). This inflammatory response in WAT of these mice was associated with the increased gene expression of the purinergic receptors $P 2 r x 4, P 2 r x 5$, and $P 2 r x 7$ as well as marked changes in gene expression levels of nucleotidemetabolizing enzymes CD39 (encoded by Entpd1) but not Cd38, CD73 (encoded by Nt5e), and Ucpl (Fig. 1a). Next to WAT, obesity and high fat diet feeding have also pronounced effects on BAT inflammatory status and results in a WAT-like morphology which is referred to as BAT whitening [2, 28]. In BAT of $o b / o b$ mice, increased Emrl expression was observed (Fig. 1b). In whitened BAT of DIO and $o b / o b$ mice, we also detected increased gene expression of P2rx4, P2rx5, and P2rx7 (Fig. 1b). Similar to Emr1, higher levels of Entpd1, $C d 38$, and Nt5e were found in BAT of $o b / o b$ mice, while no obesity-associated changes in Ucpl expression were detected. Overall, these data suggest that purinergic $\mathrm{P} 2 \mathrm{X}$ receptors 
Fig. 1 Gene expression analysis in $\mathbf{a}$ WAT and $\mathbf{b}$ BAT of lean, DIO, and $o b / o b$ mice. C57BL6/J wild-type (WT) mice were fed a normal chow (lean) or a diabetogenic high-fat diet for 16 weeks to generate lean or dietinduced obese (DIO) mice. From these mice as well as from leptindeficient $o b / o b$ mice, the expression of genes important for extracellular adrenergic signaling was determined by qPCR. Data are presented as mean \pm SEM, $* P<0.05$ a
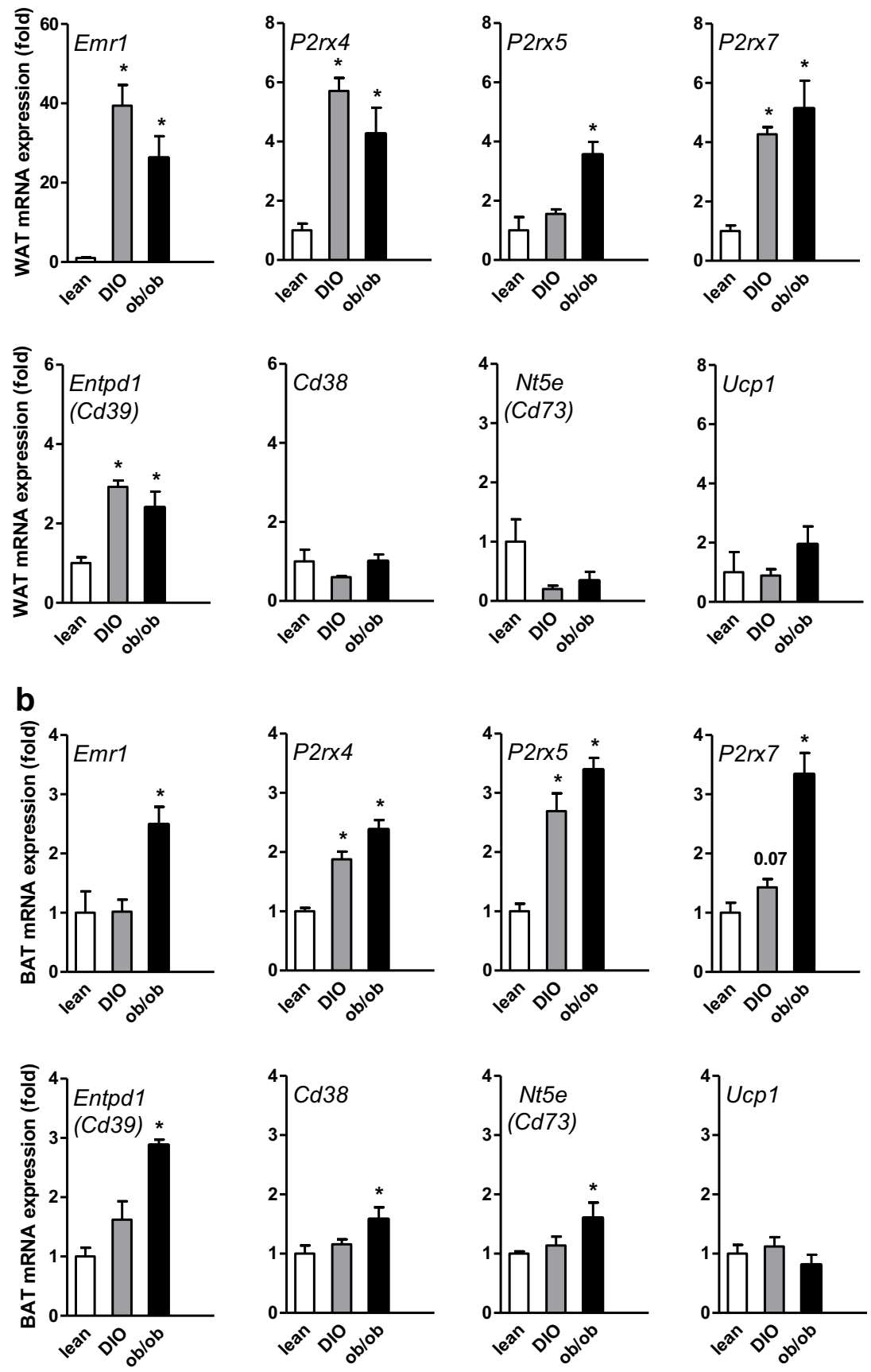

could be involved in the regulation of obesity-associated inflammatory responses in WAT and BAT.

Cold exposure leads to a catabolic condition to promote energy combustion and heat production, which is associated with tissue remodeling of WAT and BAT [2, 28]. This prompted us to test the expression of purinergic receptors in adipose tissue upon cold exposure. To overcome the issue of cellular heterogeneity within adipose tissue, we determined the expression of receptors and enzymes regulating purinergic signaling in isolated cell types of WAT and BAT from mice under control $\left(22{ }^{\circ} \mathrm{C}\right)$ and 1-day cold-activated $\left(6{ }^{\circ} \mathrm{C}\right)$ conditions. We confirmed the purity of cellular fractions based on the expression of specific markers for adipocytes (Adipoq), endothelial cells (Gpihbpl) and tissue-resident macrophages (Emrl) (Fig. 2a-c). The expression of P2rx4 was detected in both macrophages and adipocytes (Fig. 2d), while $P 2 x r 7$ was much higher in macrophages than other cell types (Fig. 2e). On the other hand, P2xr5 was only present in brown adipocytes and a tendency of higher expression in response to cold exposure was observed (Fig. 2f), which is in accordance with 

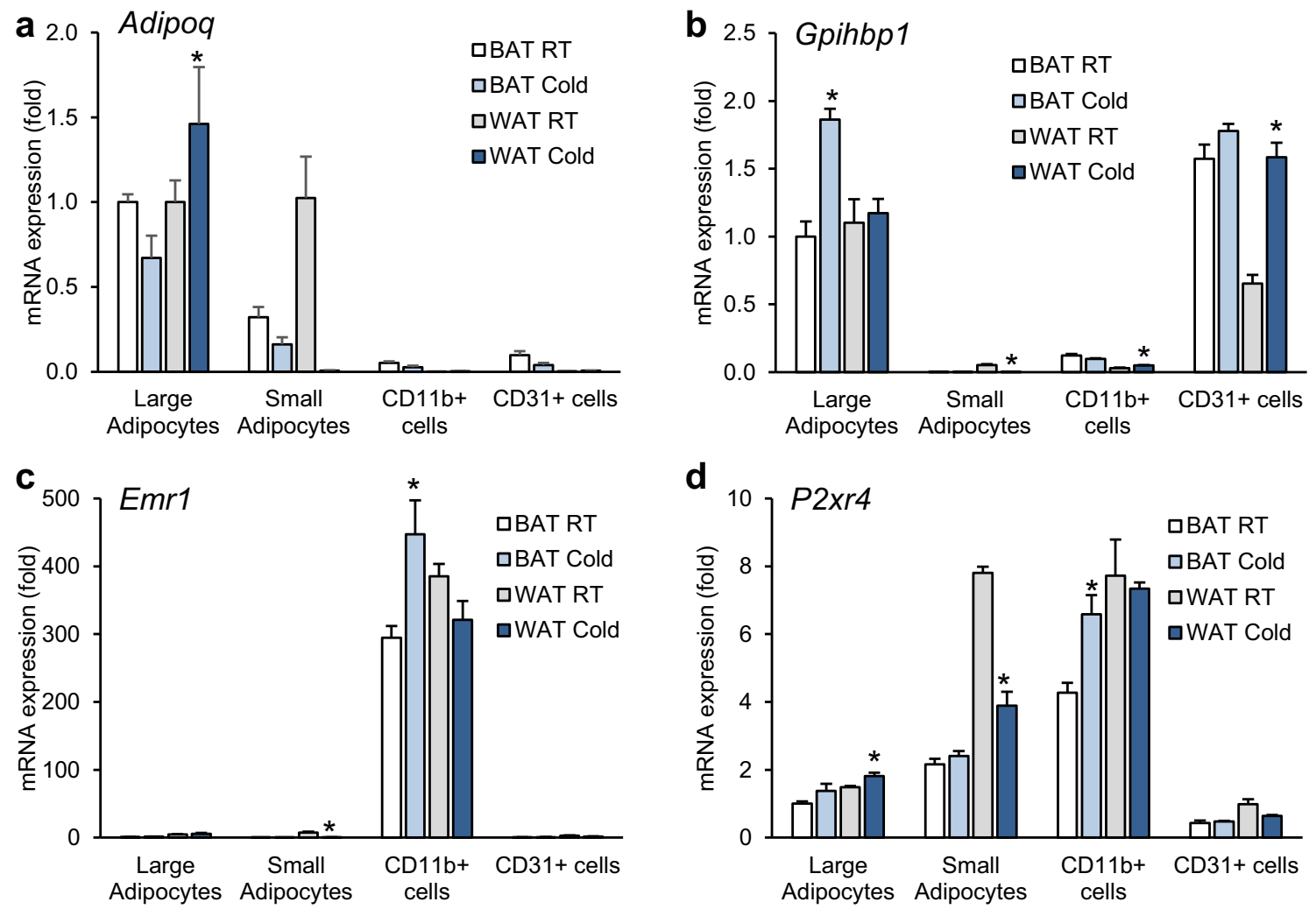

d
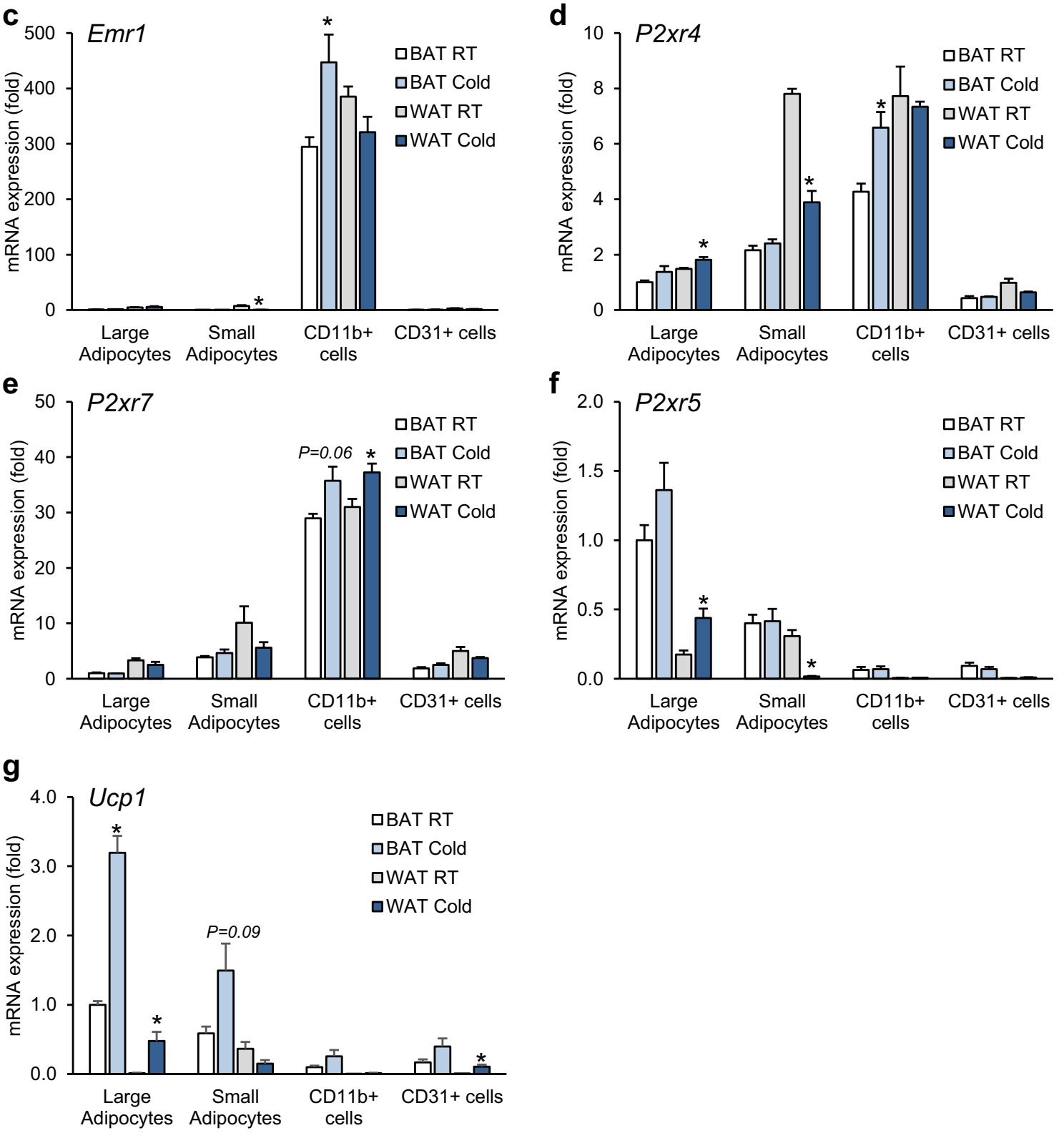

Fig. 2 Gene expression analysis in cell fractions from adipose tissue (ag). Male C57BL6/J WT mice were housed for 1 day at RT $\left(22^{\circ} \mathrm{C}\right)$ or cold $\left(4{ }^{\circ} \mathrm{C}\right)$ condition. iBAT and subWAT tissues were harvested from each group, and different cell types were isolated by MACS®. Purity of cellular fractions was verified by gene expression of cell-specific

markers for adipocytes (Adipoq), endothelial cells (Gpihbp1), and tissue resident macrophages (Emrl). The expression of P2rx4, P2rx5, P2rx7, and Ucpl was determined in all isolated cell fractions. $n=4$. Statistical analysis was done between cells of RT and cold group isolated from each tissue. Data are presented as mean \pm SEM, $* P<0.05$ 
the expression of $U c p 1$ (Fig. 2g). Taken together, these data support the notion that purinergic $\mathrm{P} 2 \mathrm{X}$ receptors could play a role in WAT and BAT remodeling in response to dietary or cold stress.

\section{Effect of P2X7 deficiency on cold-induced energy expenditure}

Two knockout mouse models have been generated to study P2rx7 function. Pfizer established P2rx7-deficient mice by inserting a neomycin cassette into exon 13 , replacing part of the C-terminus of the receptor, whereas GlaxoSmithKline generated them by inserting a LacZ transgene and neomycin cassette into exon 1 $[29,30]$. In the current study, we performed metabolic studies in the mouse model generated by Pfizer, which expresses the P2X7 $\Delta \mathrm{C}$ variant with reduced function [31]. We compared these knockout mice backcrossed onto the BALB/c and C57BL/6 backgrounds as $\mathrm{BALB} / \mathrm{c}$ mice express the functional $\mathrm{P} 451$ allele while C57BL/6 mice express the low activity variant 451L. Protein expression analyses of interscapular BAT and inguinal and gonadal WAT from wild-type and $P 2 x r 7 \mathrm{KO}$ male mice that were fed a high-fat diet for 16 weeks showed the presence of P2X7 in all adipose tissue depots in both strains (Fig. 3a). As expected, the knockout was confirmed on the BALB/c as well as on the C57BL/ 6 background.

To determine whether $\mathrm{P} 2 \mathrm{X} 7$ is involved in the regulation of adaptive thermogenesis in vivo, we measured oxygen consumption and carbon dioxide production in a temperature-controlled indirect calorimetry system. After adaptation to thermoneutral conditions $\left(30^{\circ} \mathrm{C}\right)$, we measured energy expenditure during the gradual decrease of the ambient temperature $\left(5-6^{\circ} \mathrm{C}\right.$ each day) to $6{ }^{\circ} \mathrm{C}$ (Fig. 3b-g). Each drop in the temperature resulted in increased $\mathrm{O}_{2}$ consumption (Fig. 3b, e) and $\mathrm{CO}_{2}$ production (Fig. $3 \mathrm{c}, \mathrm{f})$. However, no significant differences were observed between wild-type and $P 2 r x 7 \mathrm{KO}$ male mice on the BALB/c background regarding $\mathrm{O}_{2}$ consumption, $\mathrm{CO}_{2}$ consumption, and respiratory exchange ratio (RER; Fig. 3b-d). Although upon gradual cold exposure, $P 2 r \times 7 \mathrm{KO}$ male mice on the C57BL/6J background exhibited slightly reduced $\mathrm{O}_{2}$ consumption at some time points at low ambient temperature, $\mathrm{CO}_{2}$ consumption and RER were not significantly altered (Fig. 3e-g). Also, other metabolic parameters including food and water intake, and locomotor activity showed no significant differences between wild-type and $P 2 r x 7 \mathrm{KO}$ mice in both mouse strains studied (Supplementary Fig. 1a-f). Taken together, these results indicate a minor role for $\mathrm{P} 2 \mathrm{X} 7$ in regulating energy expenditure during cold adaptation.

\section{Effect of P2X7 deficiency on adiposity}

- In order to determine the effect of P2X7 deficiency on adiposity, we subjected $P 2 r x 7 \mathrm{KO}$ and wild-type control male mice on the BALB/c and C57BL/6 backgrounds to a HFD feeding regimen. After 16 weeks of HFD feeding, $P 2 r x 7 \mathrm{KO}$ on the $\mathrm{BALB} / \mathrm{c}$ background showed no significant difference in body weight and body weight gain compared with WT controls (Fig. 4a, b). Of note, the weight of the liver was significantly reduced by deficiency of $P 2 r x 7$ on BALB/c (Fig. 4c) but not on C57BL/6 background (see also Fig. $7 \mathrm{a}, \mathrm{b}$ ). To note, there was no significant change in fat mass or lean mass upon HFD feeding in $P 2 r x 7 \mathrm{KO}$ mice on BALB/c background (Fig. 4d). P2rx $7 \mathrm{KO}$ mice on the C57BL/6 background showed a tendency to lower body weight (Fig. 4e) and exhibited significantly reduced body weight gain at weeks 6,10 , and 16 of HFD feeding compared with WT controls (Fig. 4f). Histological analyses at the end of the experiment (HFD week 16) did not reveal any significant differences in adipocyte structure, size or number in gonadal WAT, inguinal WAT, or interscapular BAT (Fig. $4 \mathrm{~g}, \mathrm{~h}$ ) between $P 2 r \times 7 \mathrm{KO}$ and WT mice. These results suggest that P2X7 deficiency does not have a major impact on adiposity during a HFD regimen.

\section{Effect of P2X7 deficiency on inflammation in adipose tissue}

It has been shown that $\mathrm{P} 2 \mathrm{X} 7$ is involved in the activation of the inflammasome and stimulates the release of pro-inflammatory cytokines such as IL1 $\beta$ [32-34]. To determine the inflammatory state in adipose tissue of $P 2 x r 7 \mathrm{KO}$ male mice on both $\mathrm{BALB} / \mathrm{c}$ and $\mathrm{C} 57 \mathrm{BL} / 6$ backgrounds in response to HFD feeding, we performed gene expression analysis of genes encoding key players of purinergic signaling (Entpd1, Nt5e, P2rx4, P2xr5) and the inflammatory response (Tnf, Illb, Il6, Ccl2) in BAT (Fig. 5a, b) and WAT (Fig. 5c, d). The results did not show any significant differences in the expression levels of these genes in BAT (Fig. 5a, b). In gonadal WAT of both BALB/c and C57BL/6 mice, we found a slight reduction in the expression of genes encoding pro-inflammatory cytokines and markers of infiltrating immune cells in P2rx7 KO vs. WT mice (Fig. 5c, d). Consistently, we observed a modest reduction in macrophage infiltration in gonadal and inguinal WAT of P2rx7 KO compared with wild-type control mice by immunohistochemistry using antibodies against the macrophage marker Galectin-3 (Mac-2) (Fig. 5e, f). Moreover, we found a robust decrease in circulating CCL2 and IL6 plasma levels after 16 weeks on HFD in P2rx7 KO vs. WT mice in both strains (Fig. $5 \mathrm{~g}-\mathrm{j}$ ). IL1-beta and TNF-alpha could not be detected by the method used. These findings indicate a decreased systemic inflammation in response to HFD feeding in P2rx7 KO vs. WT mice. 
Fig. 3 Comparative analyses of energy expenditure in WT and P2rx7 KO mice. a Ablation of $\mathrm{P} 2 \mathrm{X} 7$ protein in adipose tissues (iBAT, interscapular BAT;

iWAT, inguinal WAT; gWAT, gonadal WAT) of male WT and $P 2 r x 7$ KO mice on the BALB/c and $\mathrm{C} 57 \mathrm{BL} / 6$ backgrounds was confirmed by Western blotting. b-g Systematic energy expenditure in obese WT and $P 2 r x 7 \mathrm{KO}$ mice on the BALB/c and $\mathrm{C} 57 \mathrm{BL} / 6$ backgrounds were determined by indirect calorimetry. Male WT and P2rx 7 $\mathrm{KO}$ mice were kept in metabolic monitoring cages for 1 week with a gradual decrease in housing temperature from 30 to $6^{\circ} \mathrm{C}$. $\mathrm{O}_{2}$ consumption, $\mathrm{CO}_{2}$ production, and respiratory exchange ratio (RER) were determined in $\mathbf{b}-\mathbf{d}$ $\mathrm{BALB} / \mathrm{c}$ and $\mathbf{e}-\mathbf{g}$ C57BL/6 mice. For all experiments, $n=6$ mice per group. Data are presented as mean \pm SEM, $* P<0.05$

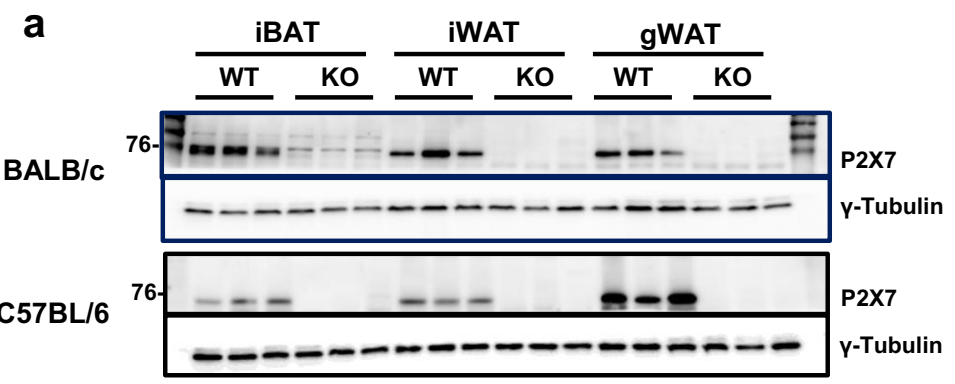

b
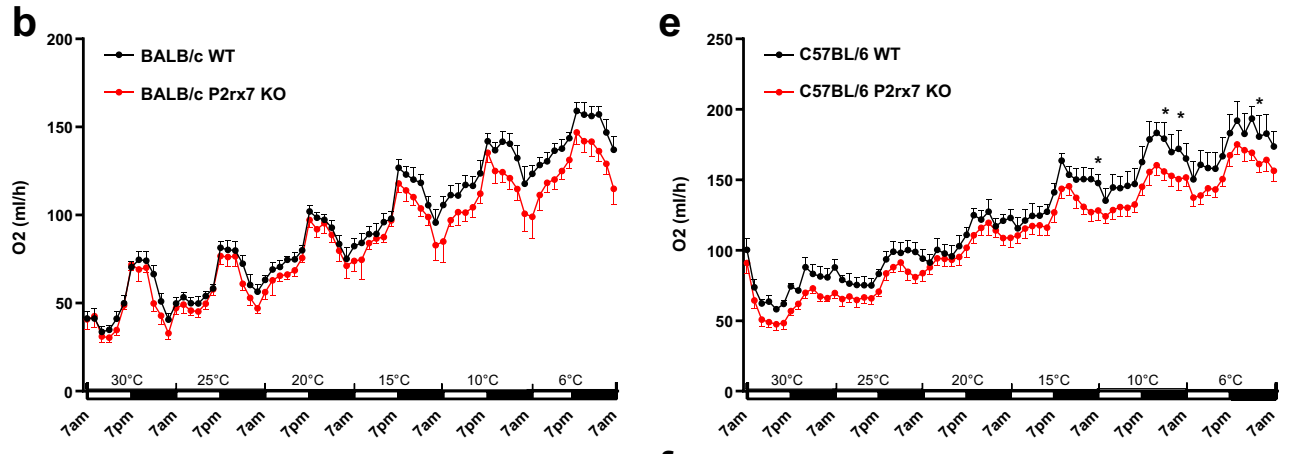

C

f
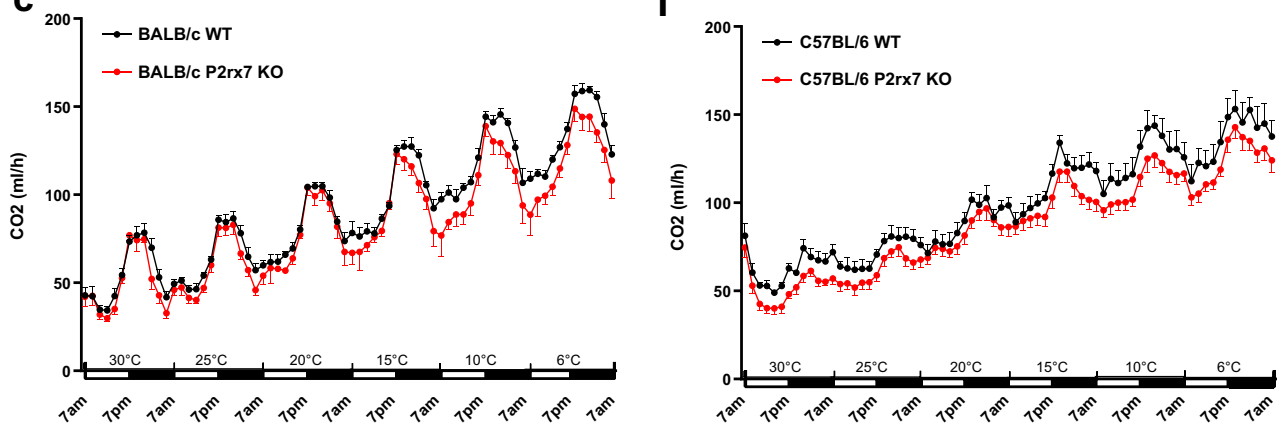

d

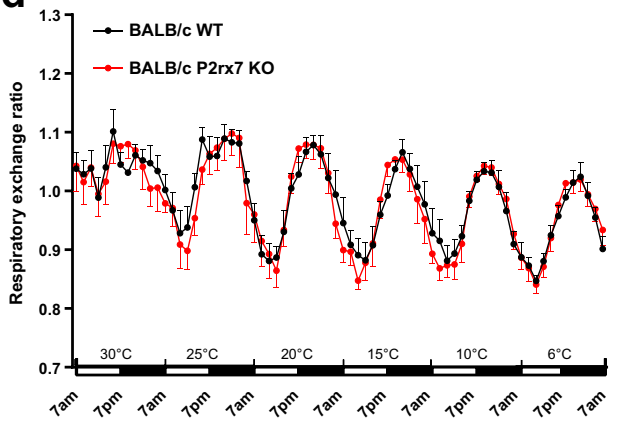

g

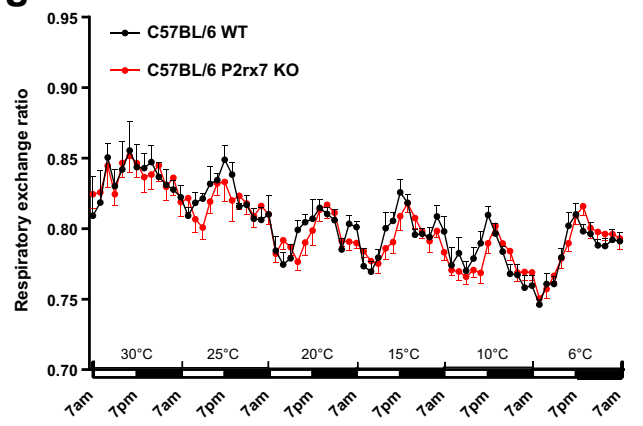

Next, we determined the impact of P2X7 deficiency on glucose homeostasis and insulin sensitivity in HFD-induced obesity. Glucose homeostasis, as determined by the oral glucose tolerance test (Fig. 6a, b) and by plasma levels of insulin (Fig. 6c, f), triglycerides (Fig. 6d, g), and cholesterol (Fig. $6 \mathrm{e}, \mathrm{h}$ ), was similar between $P 2 x r 7 \mathrm{KO}$ and WT male mice on both BALB/c and C57BL/6 backgrounds. Overall, these results suggest that $\mathrm{P} 2 \mathrm{X} 7$ has a moderate effect on the inflammatory milieu in WAT but has only little if any influence on whole body glucose homeostasis.

\section{Effect of P2X7 deficiency on hepatic inflammation}

The results presented so far indicate that $\mathrm{P} 2 \mathrm{X} 7$ plays only a minor role in metabolic inflammation in adipose tissue. On the other hand, we observed lower IL6 and CCL2 plasma levels (Fig. $5 \mathrm{~g}-\mathrm{j}$ ) and in parallel lower liver tissue weight as well as hepatic triglyceride and cholesterol levels (Fig. 7a-d) in P2rx 7 $\mathrm{KO}$ male mice on the BALB/c background. This prompted us to perform gene expression analysis to determine the inflammatory state in the liver of $P 2 r x 7 \mathrm{KO}$ male mice after 16 weeks 
Fig. 4 Diet-induced obesity studies in WT and $P 2 r x 7 \mathrm{KO}$ mice on the BALB/c and C57BL/ 6 backgrounds. Male WT and $P 2 r x 7$ KO mice were kept on a HFD for 16 weeks. a Body weight, $\mathbf{b}$ body weight gain, $\mathbf{c}$ organ weights, and $\mathbf{d}$ body fat composition was determined in $P 2 r x 7 \mathrm{KO}$ mice on BALB/c background. e Body weight and $\mathbf{f}$ body weight gain was determined in $P 2 r x 7 \mathrm{KO}$ mice on C57BL/6 background. $n=5-10$ mice per group. g, h Representative microphotographs of gWAT, iWAT, and iBAT after hematoxylin and eosin (H\&E) staining in $P 2 r x 7 \mathrm{KO}$ vs. WT mice. Data are presented as mean \pm SEM, $* P<0.05$ a

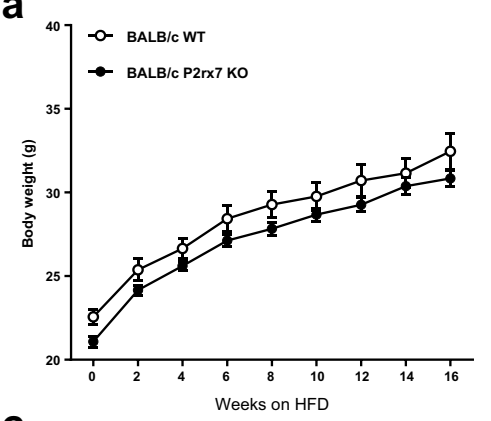

C

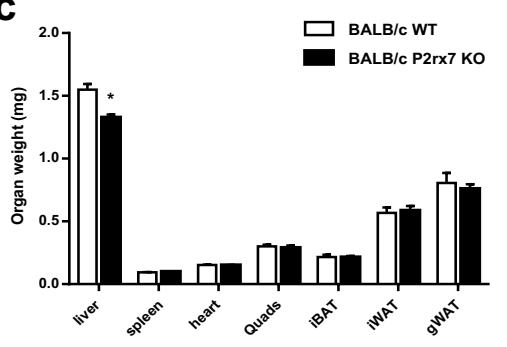

e

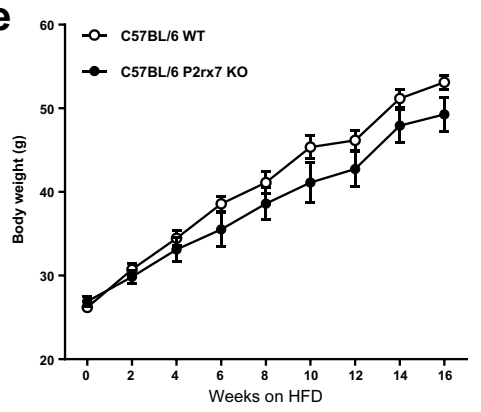

g

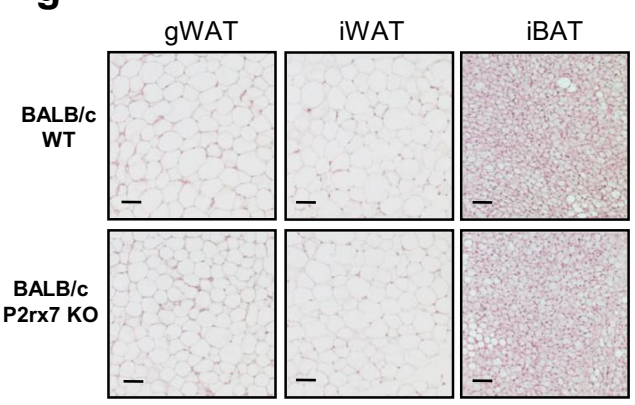

b

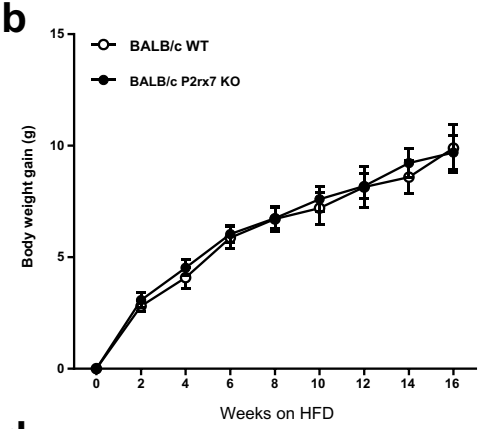

d

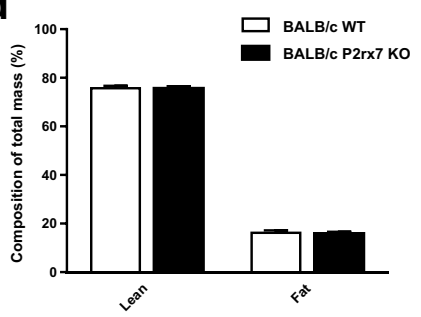

f

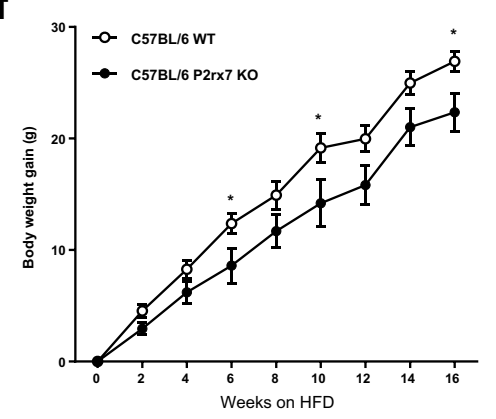

h

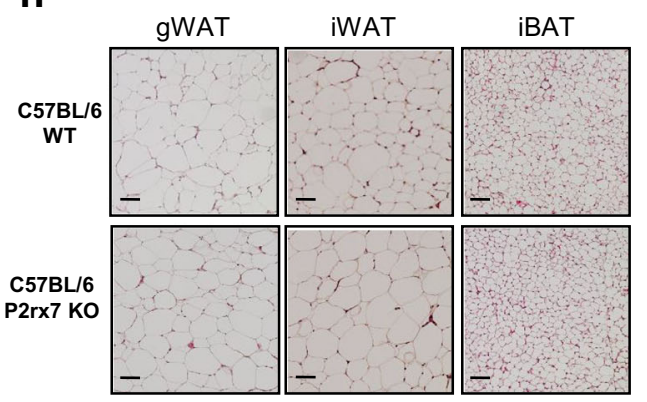

of HFD feeding. Compared with wild-type mice, we found reduced gene expression of $T n f$ and $C c l 2$ in liver of $P 2 r x 7 \mathrm{KO}$ BALB/c mice (Fig. 7e). On the C57BL/6 background, there was a similar trend towards reduced expression, but this did not reach statistical significance (Fig. 7f). These results indicate that systemic inflammation in response to HFD-feeding is modulated more by hepatic $\mathrm{P} 2 \mathrm{X} 7$ than by adipose $\mathrm{P} 2 \mathrm{X} 7$.

\section{Discussion}

The P2X7 ion channel is highly expressed in immune cells and is also found in other cell types such as epithelia, endothelia, osteoblasts, and fibroblasts [35]. Upon proinflammatory stimulation and activation, $\mathrm{P} 2 \mathrm{X} 7$ coordinates cytokine release, changes in plasma membrane lipid distribution, and cell death processes $[14,17,36]$. In humans, visceral and subcutaneous adipose tissues express functional P2X7 that can be involved in secretion of inflammatory cytokines such as IL6, TNF $\alpha$, and PAI1 [37]. In obese individuals, increased expression of P2X7 correlates with NLRP3 inflammasome activation and secretion of IL1 $\beta$ [38]. This was correlated with body mass index and metabolic syndrome score. It remains unclear which cell type (adipocytes or infiltrating immune cells) mediates this process. On the other hand, studies performed using mouse model do not show the 
a

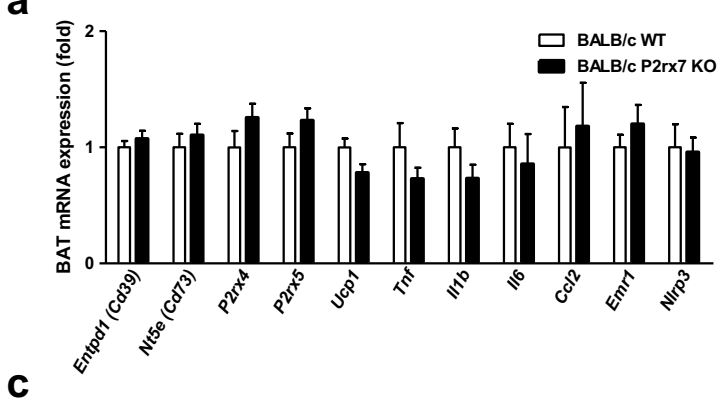

C

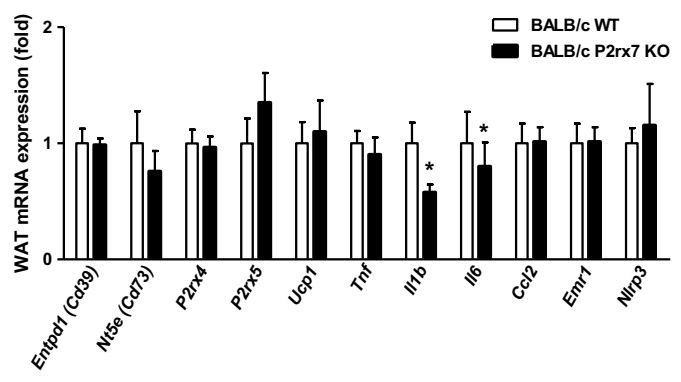

e

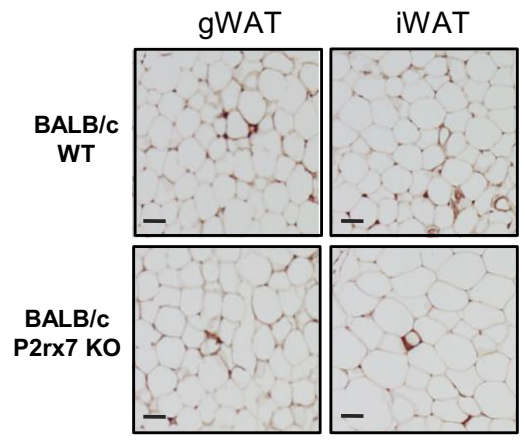

g

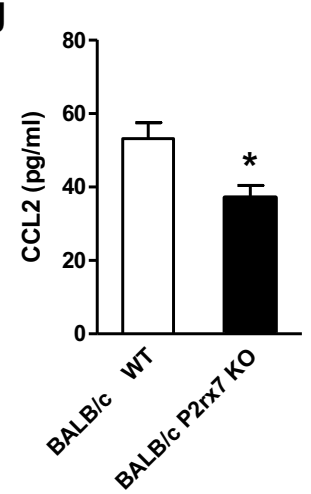

h

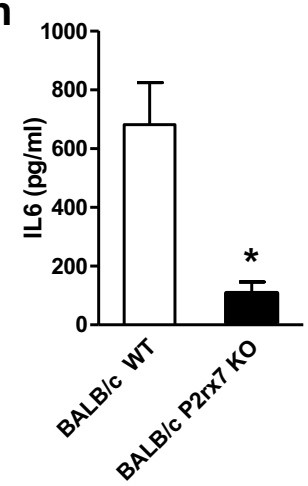

Fig. 5 Inflammatory status in BAT and WAT of obese WT and P2rx7 $\mathrm{KO}$ mice on the BALB/c and C57BL/6 backgrounds. Male WT and $P 2 r x 7 \mathrm{KO}$ mice were fed HFD for 16 weeks, and the gene expression of inflammatory markers was determined in $\mathbf{a}, \mathbf{b}$ BAT and $\mathbf{c}, \mathbf{d} \mathrm{gWAT}$ by qPCR. e, f Representative microphotographs of anti-MAC-2 immune

involvement of P2X7 in obesity-associated inflammasome activation [39]. Sun et al. showed that $P 2 r x 7 \mathrm{KO}$ mice on the $\mathrm{C} 57 \mathrm{BL} / 6$ background were not protected from dietinduced obesity and associated adipose inflammation. In another study using 9-month-old male P2rx $7 \mathrm{KO}$ mice, P2X7 was suggested to have a role in adipogenesis and lipid

b

d
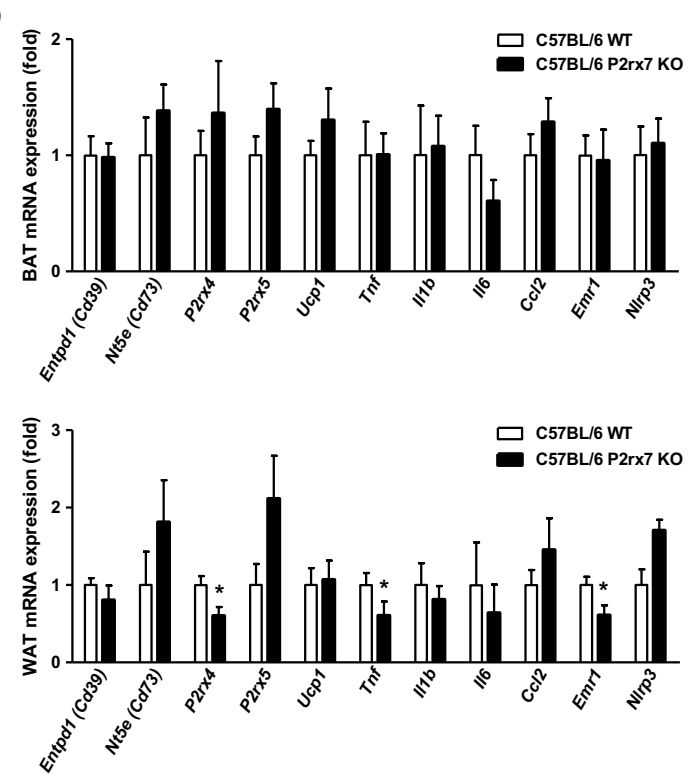

f

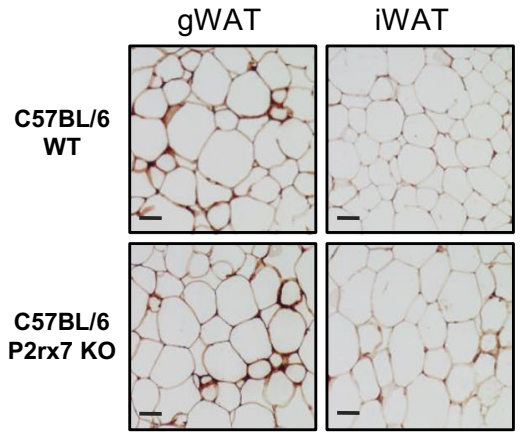

i

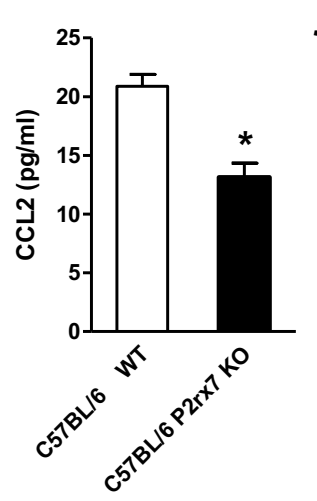

j

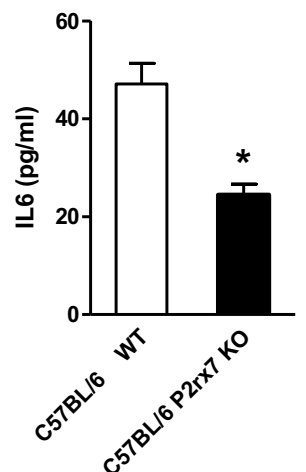

staining in gonadal (gWAT) and inguinal (iWAT) adipose tissues of WT and P2rx 7 KO mice on HFD. Plasma $\mathbf{g}, \mathbf{i}$ CCL2 and $\mathbf{h}, \mathbf{j}$ IL6 levels were determined in HFD fed WT and $P 2 r x 7 \mathrm{KO}$ mice on the $\mathbf{g}, \mathbf{h} \mathrm{BALB} / \mathrm{c}$ and $\mathbf{i}, \mathbf{j}$ C57BL/ 6 backgrounds by ELISA. $n=5-10$ mice per group. Data are presented as mean \pm SEM, $* P<0.05$

metabolism [40]. However, these authors also did not detect any significant effects on metabolic parameters in females as well as 6-month or 12-month-old male $P 2 r x 7 \mathrm{KO}$ mice, which is in line with the data of the current study. Thus, the role of P2X7 in adipocyte metabolism and intercellular communication under pathophysiological condition remains unclear. 
Fig. 6 Glucose homeostasis in obese WT and $P 2 r x 7 \mathrm{KO}$ mice. a, b Glucose tolerance test in HFD fed male WT and $P 2 r x 7 \mathrm{KO}$ mice on the $\mathbf{a} \mathrm{BALB} / \mathrm{c}$ and $\mathbf{b} \mathrm{C} 57 \mathrm{BL} / 6$ backgrounds. Plasma $\mathbf{c}, \mathbf{f}$ insulin, $\mathbf{d}, \mathbf{g}$ triglyceride, and $\mathbf{e}, \mathbf{h}$ cholesterol levels were measured using commercial kits. $n=5-10$ mice per group. Data are presented as mean $\pm \mathrm{SEM}$, $* P<0.05$
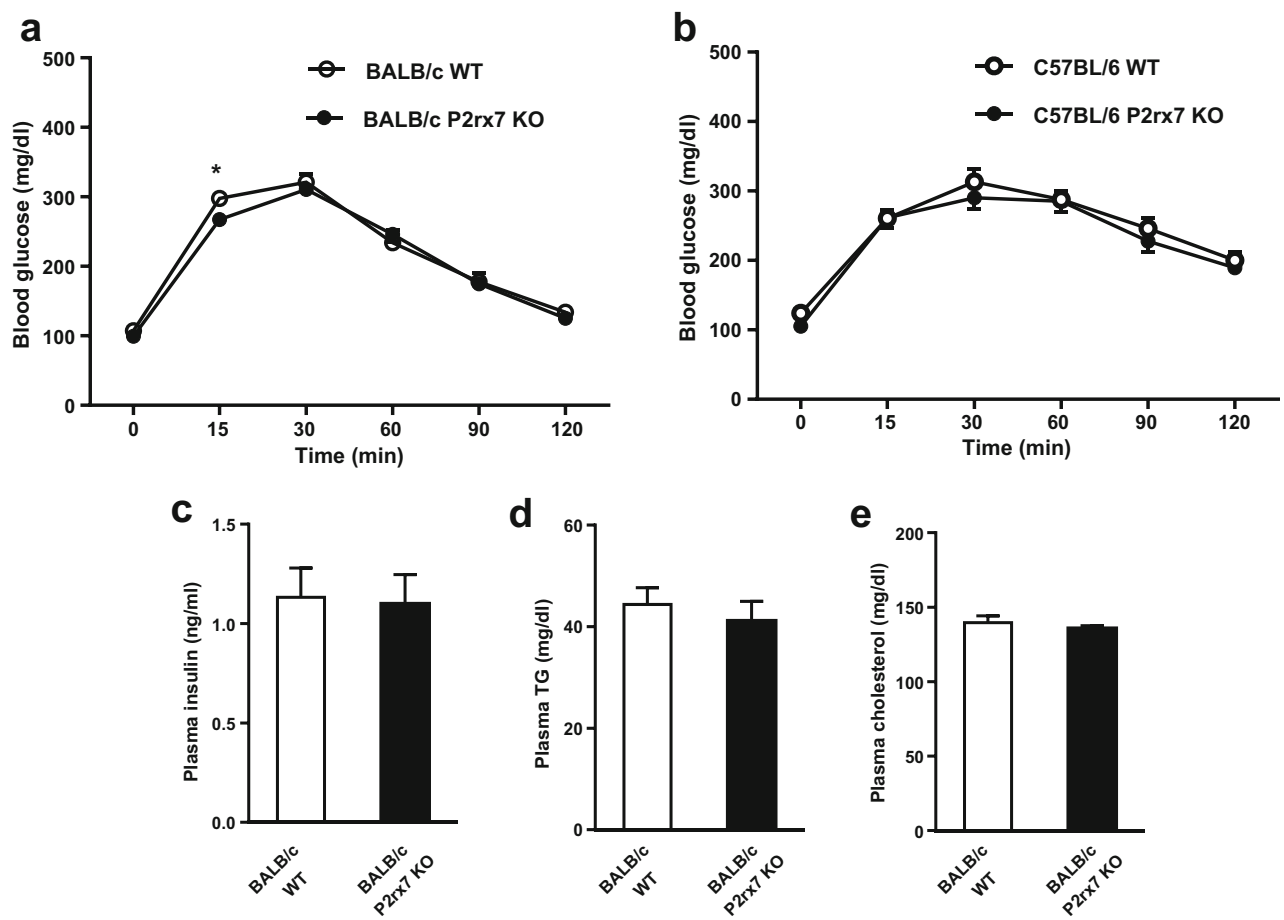

d

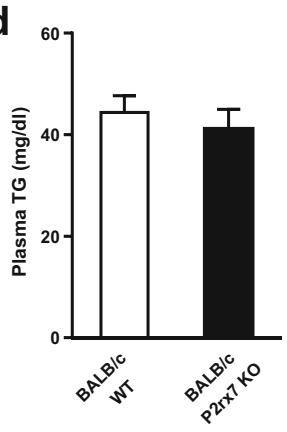

e
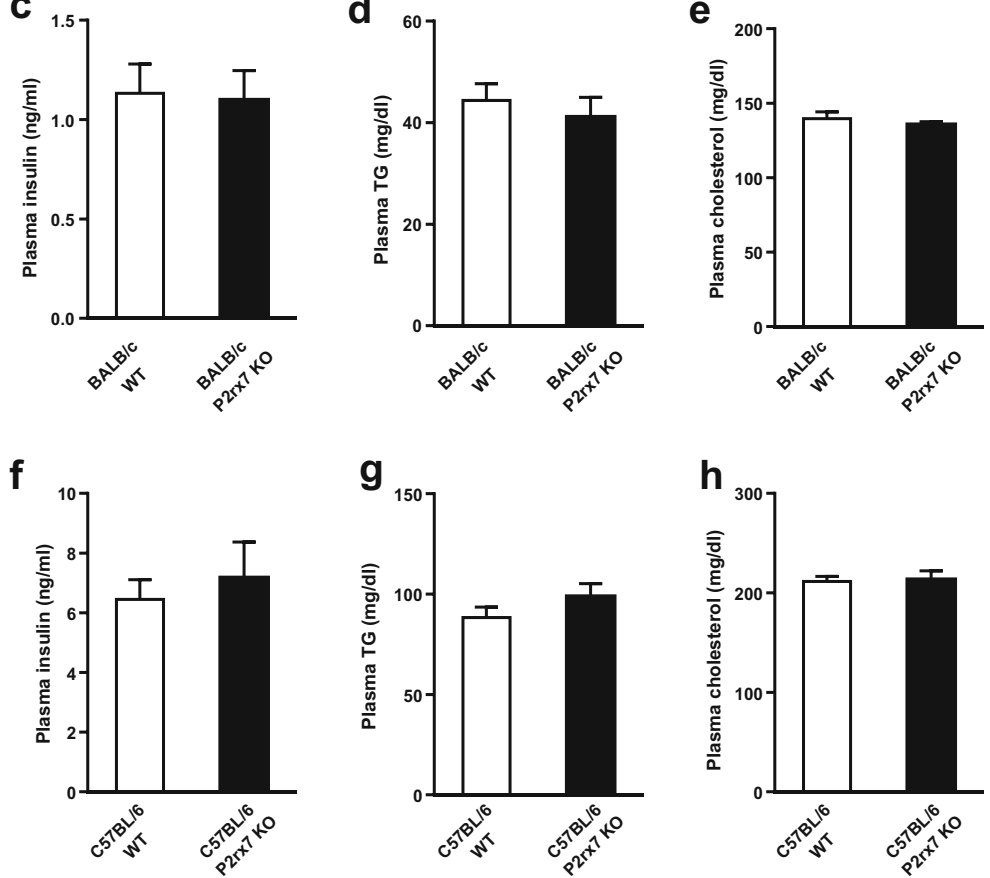

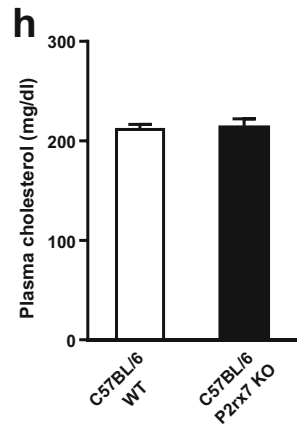

In adipose tissue, extracellular ATP is mainly released from presynaptic neural cells of sympathetic nerves. CD39 is a rate limiting ectoenzyme that hydrolyses ATP/ADP to AMP, while CD73 degrades AMP to adenosine. Thus, the enzymatic activities of CD39 and CD73 play crucial roles in determining duration and magnitude of purinergic signaling [41]. Recently, it was shown that ATP acting via P2X7 promotes a Th17 polarizing microenvironment in WAT [42]. In vivo studies have shown a role for CD39 in insulin signaling and liver metabolism, whereas CD73 plays a role in intracellular lipid metabolism in adipose tissue and muscle [43-45]. We do not have insight into the relevance of this extracellular purinergic signaling in adipose tissue for metabolic crosstalk between infiltrating and tissue-resident immune cells and paracrine signaling between immune cells and adipocytes. Here we show that both nutritional stress and genetic model of obesity result in increased expression of $\mathrm{P} 2 \mathrm{X} 7$ which is associated with increased macrophage infiltration within adipose tissue and also increased expression of CD39 and CD73.
Adipose tissue shows high heterogeneity, wherein at least half of the cells are non-adipocytes and is composed of several cell types namely adipocytes, fibroblasts, immune cells, and endothelial cells $[46,47]$. Multiple cell types add to the complexity of the cellular interaction in adipose tissue and the relative expression and distribution of $\mathrm{P} 2 \mathrm{X} 7$ within different cell types of adipose tissues have not been fully elucidated. Through cell separation studies in adipose tissue, we show the robust expression of P2X7 in macrophages compared with other cell types. These results are critical towards understanding the cell type-specific contribution of $P 2 r x 7$ during the progression of obesity and macrophage infiltration.

We sought to ascertain the role of $\mathrm{P} 2 \mathrm{X} 7$ in the diet-induced obese mouse model. Previous studies have investigated the role of $\mathrm{P} 2 \mathrm{X} 7$ in disease states using P2rx7-deficient mice on the $\mathrm{C} 57 \mathrm{BL} / 6$ background. However, the C57BL/6 mouse strain has a naturally occurring mutation that leads to replacement of the proline residue at position 451 by a leucine residue in the cytoplasmic tail of P2X7 [20]. The distribution of the 
Fig. 7 Effect on liver metabolic parameters in obese WT and $P 2 r x 7 \mathrm{KO}$ mice. Male WT and $P 2 r x 7 \mathrm{KO}$ mice were kept on a HFD for 16 weeks. a, b Liver weight was determined in $P 2 r x 7$ KO mice compared with WT controls on the $\mathbf{a} \mathrm{BALB} / \mathrm{c}$ and $\mathbf{b}$ C57BL/6 backgrounds. Liver c triglyceride (TG) and $\mathbf{d}$ cholesterol levels were determined and normalized to protein concentration. e, f Gene expression of inflammatory markers in the liver of WT and $P 2 r x 7 \mathrm{KO}$ mice on the e BALB/c and $\mathbf{f}$ C57BL $/ 6$ background. $n=$ $5-10$ mice per group. Data are presented as mean \pm SEM, $* P<0.05$
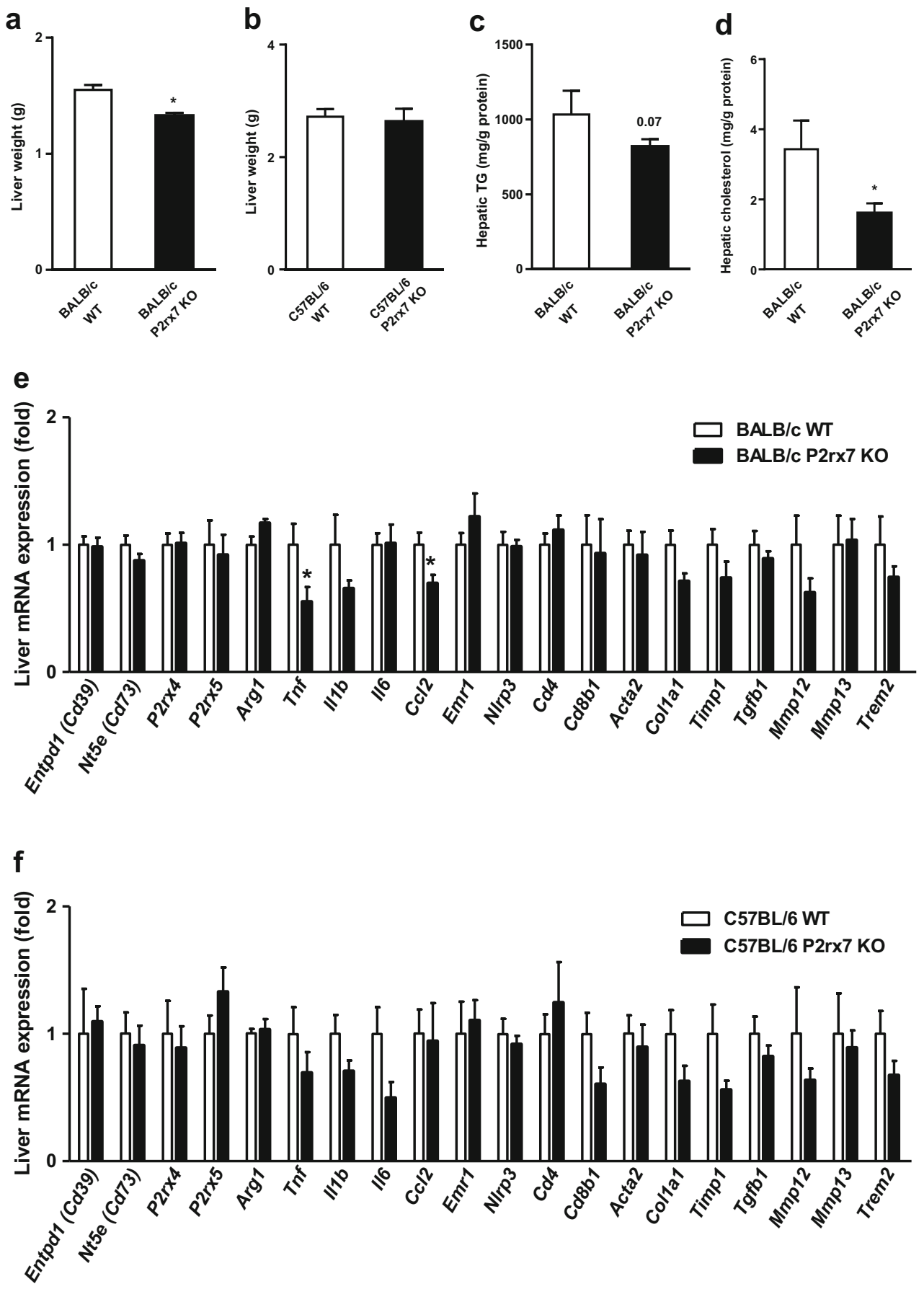

allelic version of P451L SNP is different in BALB/c and $\mathrm{C} 57 \mathrm{BL} / 6$ mice. BALB/c mice and $\mathrm{C} 57 \mathrm{BL} / 6$ carry $\mathrm{P} 451$ and 451L alleles, respectively. P2X7 functional studies show that $\mathrm{T}$ cells from BALB/c mice have significantly higher sensitivity to ATP than those obtained from C57BL/6 mice [20]. Apart from in vitro studies, the P451L SNP has been implicated in disease development in two studies. First, an association between the P451L SNP and neuropathic pain in mice has been reported in genome-wide linkage analysis studies [23]. Second, a bone phenotype was found to be associated with P451L SNP in C57BL/6 mice [24]. Based on these studies, it has been suggested that the P451L SNP may underestimate purinergic receptor function in $P 2 r x 7 \mathrm{KO}$ mice on the C57BL/6 background compared with BALB/c mice [20, 48]. In order to address the impact of strain differences on metabolic phenotype, we compared the pathophysiological events in P2rx $7 \mathrm{KO}$ mice on both, C57BL/6 and BALB/c backgrounds. Notably, P2X7 deficiency in both the strains did not influence glucose intolerance or insulin resistance associated with diet-induced obesity. Moreover, neither body weight 
nor adiposity was altered by $P 2 r x 7$ deficiency. Also, plasma parameters such as glucose, insulin, triglycerides, and cholesterol levels were unchanged, indicating that even the full functional $\mathrm{P} 2 \mathrm{X} 7$ receptor of $\mathrm{BALB} / \mathrm{c}$ mice does not play a major role in adipose metabolic inflammation.

There have been other recent studies using $P 2 r x 7 \mathrm{KO}$ mice on the C57BL/6 background, and as is a typical of metabolic phenotyping studies, our findings show some striking similarities as well as some important differences. Consistent with our work, Sun et al. did not observe any significant change in body weight, insulin sensitivity, or inflammatory state upon 12-week HFD feeding in P2rx7 KO mice on the C57BL/6 background [39]. On the other hand, Beaucage et al. reported that 9-month-old male P2rx $7 \mathrm{KO}$ mice on the C57BL/6 background exhibited increased body weight, epididymal fat pad weight, and ectopic lipid accumulation in kidney, pancreas, and extraorbital lacrimal gland [40]. However, no significant metabolic differences were observed in female, and younger ( $<6$ months) or older ( $>$ 12 months) mice [40]. Taken together, these data suggest that $P 2 r x 7$ may play only a minor role if any in insulin resistance caused by overnutrition in mouse models.

Addressing the effect of P2X7 on BAT is complex and may be different between rodents and humans [49]. P2X7 has been considered important for cellular energy homeostasis, whole body energy metabolism, and fatty acid oxidation [50], although our data question this notion. Giacovazzo et al. determined energy expenditure, $\mathrm{O}_{2}$ consumption, and RER in a narrow window of 24-h acclimatization followed by 24 -h measurement using 20 month-old female mice. We found on both strains that P2X7 deficiency did not result in significant alterations in energy expenditure or fuel utilization. Also, the gene expression of $U c p 1$ and other thermogenic markers was not significantly altered in BAT when $P 2 r x 7$ was inactivated. Our in vivo studies showed increased $P 2 r \times 5$ mRNA level in brown adipocytes compared with other cell types in BAT that was induced upon cold exposure (Fig. 2f). These results are consistent with previous study identifying $P 2 r \times 5$ as a novel cell surface marker for brown adipocytes in mice and humans [51-53]. Despite no change in P2r $x 5$ mRNA levels in BAT, P2rx7 KO mice on HFD showed increased P2X5 protein levels compared with WT controls indicating a potential compensatory mechanism between $P 2 r \times 5$ and $P 2 r x 7$ (Supplementary Fig. 2a). Interestingly, $P 2 r x 4$ mRNA expression is reduced in WAT of $P 2 r x 7$-deficient mice (Fig. 5d), which may points towards a mutual regulation of these $\mathrm{P} 2 \mathrm{x}$ receptors within adipose tissues under conditions of high caloric intake. Taken together, our data suggest that P2X7 exerts only minor effects on the thermogenic function of BAT. One possible interpretation of the finding that $P 2 r x 7$ is dispensable for the development of diet-induced obesity and insulin resistance is that other members of the $\mathrm{P} 2 \mathrm{X}$ receptor family alone or in combination with other members may play a more important role in these processes. Probably, also aging-related metabolic adaptation may play a role in manifesting metabolic dysfunctional processes. In such a scenario, identifying interacting partners through IP and Co-IP experiments would help shed light on these pathways.

One interesting result from our study was that $P 2 r x 7 \mathrm{KO}$ mice showed reduced liver weight, liver triglycerides, and cholesterol levels upon HFD feeding. Furthermore, the reduced expression of pro-inflammatory genes and reduced levels of plasma cytokines CCL2 and IL6 in P2rx $7 \mathrm{KO}$ vs. WT mice may indicate a role for P2X7 in liver upon nutritional inflammatory stimulus. Surprisingly, a recent study reported dyslipidemia and hepatic steatosis along with increased weight gain in $P 2 r x 7 \mathrm{KO}$ mice [54]. In this study, lipogenic pathways were shown to be affected, indicating that $\mathrm{P} 2 \mathrm{X} 7$ deficiency may deregulate liver function under severe hepatic pathological conditions.

In conclusion, even in $\mathrm{BALB} / \mathrm{c}$ mice, which in contrast to $\mathrm{C} 57 \mathrm{BL} / 6$ mice express the fully functional receptor, P2X7 deficiency does not have a significant effect on the function of adipose tissues under conditions of dietary or cold stress. The emerging picture suggests that a possible role of $\mathrm{P} 2 \mathrm{X} 7$ is not mediated by HFDinduced adipose tissue hypertrophy and inflammation but may rather be modulated by inflammation in the liver. It is also possible that the murine P451L SNP exerts critical cell type-specific effects that contribute to the diversity of receptor-mediated responses in studies addressing the role of $\mathrm{P} 2 \mathrm{X} 7$ in health and disease.

Acknowledgments The authors gratefully acknowledge members of the Heeren lab for their helpful suggestions and discussion. We thank Sandra Ehret, Paul Pertzborn, Eva Maria Azizi, and Birgit Henkel for excellent technical support.

Author contributions The study was designed by TT, MK, FN, and JH; the experiments were executed by TT, IE, MK, TS, NS, MJ and analyzed by MH, TT, MK, and JH. TT, FN, MK, and JH wrote the manuscript.

Funding Open Access funding enabled and organized by Projekt DEAL. This work was supported by a China Scholarship to TT, an Alexander von Humboldt Postdoctoral Research Fellowship to MK, and by DFG grants HE3645/10-1 and project-ID: 335447727-SFB 1328 to F.N. and $\mathrm{JH}$.

\section{Compliance with ethical standards}

Conflicts of interest The authors declare that they have no conflicts of interest.

Ethical approval All applicable international, national, and/or institutional guidelines for the care and use of animals were followed. This article does not contain any studies with human participants performed by any of the authors.

Open Access This article is licensed under a Creative Commons Attribution 4.0 International License, which permits use, sharing, adaptation, distribution and reproduction in any medium or format, as long as you give appropriate credit to the original author(s) and the source, provide a link to the Creative Commons licence, and indicate if changes were made. The images or other third party material in this article are included in the article's Creative Commons licence, unless indicated 
otherwise in a credit line to the material. If material is not included in the article's Creative Commons licence and your intended use is not permitted by statutory regulation or exceeds the permitted use, you will need to obtain permission directly from the copyright holder. To view a copy of this licence, visit http://creativecommons.org/licenses/by/4.0/.

\section{References}

1. Cannon B, Nedergaard J (2004) Brown adipose tissue: function and physiological significance. Physiol Rev 84(1):277-359. https://doi. org/10.1152/physrev.00015.2003

2. Bartelt A, Heeren J (2014) Adipose tissue browning and metabolic health. Nat Rev Endocrinol 10(1):24-36. https://doi.org/10.1038/ nrendo.2013.204

3. Heeren J, Scheja L (2018) Brown adipose tissue and lipid metabolism. Curr Opin Lipidol 29(3):180-185. https://doi.org/10.1097/ MOL.0000000000000504

4. Rosen ED, Spiegelman BM (2014) What we talk about when we talk about fat. Cell 156(1-2):20-44. https://doi.org/10.1016/j.cell. 2013.12.012

5. Kumari M, Heeren J, Scheja L (2018) Regulation of immunometabolism in adipose tissue. Semin Immunopathol 40(2):189-202. https://doi.org/10.1007/s00281-017-0668-3

6. Hotamisligil GS (2017) Inflammation, metaflammation and immunometabolic disorders. Nature 542(7640):177-185. https:// doi.org/10.1038/nature21363

7. Xu H, Barnes GT, Yang Q, Tan G, Yang D, Chou CJ, Sole J, Nichols A, Ross JS, Tartaglia LA, Chen H (2003) Chronic inflammation in fat plays a crucial role in the development of obesityrelated insulin resistance. J Clin Invest 112(12):1821-1830. https:// doi.org/10.1172/JCI19451

8. Weisberg SP, McCann D, Desai M, Rosenbaum M, Leibel RL, Ferrante AW Jr (2003) Obesity is associated with macrophage accumulation in adipose tissue. J Clin Invest 112(12):1796-1808. https://doi.org/10.1172/JCI19246

9. Weisberg SP, Hunter D, Huber R, Lemieux J, Slaymaker S, Vaddi K, Charo I, Leibel RL, Ferrante AW Jr (2006) CCR2 modulates inflammatory and metabolic effects of high-fat feeding. J Clin Invest 116(1):115-124. https://doi.org/10.1172/JCI24335

10. Kanda H, Tateya S, Tamori Y, Kotani K, Hiasa K, Kitazawa R, Kitazawa S, Miyachi H, Maeda S, Egashira K, Kasuga M (2006) MCP-1 contributes to macrophage infiltration into adipose tissue, insulin resistance, and hepatic steatosis in obesity. J Clin Invest 116(6):1494-1505. https://doi.org/10.1172/JCI26498

11. Vozarova B, Weyer C, Hanson K, Tataranni PA, Bogardus C, Pratley RE (2001) Circulating interleukin-6 in relation to adiposity, insulin action, and insulin secretion. Obes Res 9(7):414-417. https://doi.org/10.1038/oby.2001.54

12. Pradhan AD, Manson JE, Rifai N, Buring JE, Ridker PM (2001) Creactive protein, interleukin 6 , and risk of developing type 2 diabetes mellitus. Jama 286(3):327-334. https://doi.org/10.1001/jama. 286.3.327

13. Zimmermann H, Zebisch M, Strater N (2012) Cellular function and molecular structure of ecto-nucleotidases. Purinergic Signal 8(3): 437-502. https://doi.org/10.1007/s11302-012-9309-4

14. Linden J, Koch-Nolte F, Dahl G (2019) Purine release, metabolism, and signaling in the inflammatory response. Annu Rev Immunol 37:325-347. https://doi.org/10.1146/annurev-immunol-051116052406

15. Corriden R, Insel PA (2010) Basal release of ATP: an autocrineparacrine mechanism for cell regulation. Sci Signal 3(104):re1. https://doi.org/10.1126/scisignal.3104re1
16. Orioli E, De Marchi E, Giuliani AL, Adinolfi E (2017) P2X7 receptor orchestrates multiple signalling pathways triggering inflammation, autophagy and metabolic/trophic responses. Curr Med Chem 24(21):2261-2275. https://doi.org/10.2174/ 0929867324666170303161659

17. Bartlett R, Stokes L, Sluyter R (2014) The P2X7 receptor channel: recent developments and the use of $\mathrm{P} 2 \mathrm{X} 7$ antagonists in models of disease. Pharmacol Rev 66(3):638-675. https://doi.org/10.1124/pr. 113.008003

18. Weber FC, Esser PR, Muller T, Ganesan J, Pellegatti P, Simon MM, Zeiser R, Idzko M, Jakob T, Martin SF (2010) Lack of the purinergic receptor $\mathrm{P} 2 \mathrm{X}(7)$ results in resistance to contact hypersensitivity. J Exp Med 207(12):2609-2619. https://doi.org/10.1084/ jem.20092489

19. Wilhelm K, Ganesan J, Muller T, Durr C, Grimm M, Beilhack A, Krempl CD, Sorichter S, Gerlach UV, Juttner E, Zerweck A, Gartner F, Pellegatti P, Di Virgilio F, Ferrari D, Kambham N, Fisch P, Finke J, Idzko M, Zeiser R (2010) Graft-versus-host disease is enhanced by extracellular ATP activating P2X7R. Nat Med 16(12):1434-1438. https://doi.org/10.1038/nm.2242

20. Adriouch S, Dox C, Welge V, Seman M, Koch-Nolte F, Haag F (2002) Cutting edge: a natural P451L mutation in the cytoplasmic domain impairs the function of the mouse P2X7 receptor. J Immunol 169(8):4108-4112. https://doi.org/10.4049/jimmunol. 169.8.4108

21. Le Stunff H, Auger R, Kanellopoulos J, Raymond MN (2004) The Pro-451 to Leu polymorphism within the C-terminal tail of P2X7 receptor impairs cell death but not phospholipase $\mathrm{D}$ activation in murine thymocytes. J Biol Chem 279(17):16918-16926. https:// doi.org/10.1074/jbc.M313064200

22. Suadicani SO, Iglesias R, Spray DC, Scemes E (2009) Point mutation in the mouse $\mathrm{P} 2 \mathrm{X} 7$ receptor affects intercellular calcium waves in astrocytes. ASN Neuro 1(1):AN20090001. https://doi.org/10. 1042/AN20090001

23. Sorge RE, Trang T, Dorfman R, Smith SB, Beggs S, Ritchie J, Austin JS, Zaykin DV, Vander Meulen H, Costigan M, Herbert TA, Yarkoni-Abitbul M, Tichauer D, Livneh J, Gershon E, Zheng M, Tan K, John SL, Slade GD, Jordan J, Woolf CJ, Peltz G, Maixner W, Diatchenko L, Seltzer Z, Salter MW, Mogil JS (2012) Genetically determined P2X7 receptor pore formation regulates variability in chronic pain sensitivity. Nat Med 18(4):595599. https://doi.org/10.1038/nm.2710

24. Syberg S, Petersen S, Beck Jensen JE, Gartland A, Teilmann J, Chessell I, Steinberg TH, Schwarz P, Jorgensen NR (2012) Genetic background strongly influences the bone phenotype of P2X7 receptor knockout mice. J Osteoporos 2012:391097391099. https://doi.org/10.1155/2012/391097

25. Labasi JM, Petrushova N, Donovan C, McCurdy S, Lira P, Payette MM, Brissette W, Wicks JR, Audoly L, Gabel CA (2002) Absence of the P2X7 receptor alters leukocyte function and attenuates an inflammatory response. J Immunol 168(12):6436-6445. https:// doi.org/10.4049/jimmunol.168.12.6436

26. Heine M, Fischer AW, Schlein C, Jung C, Straub LG, Gottschling K, Mangels N, Yuan Y, Nilsson SK, Liebscher G, Chen O, Schreiber R, Zechner R, Scheja L, Heeren J (2018) Lipolysis triggers a systemic insulin response essential for efficient energy replenishment of activated brown adipose tissue in mice. Cell Metab 28(4):644-655 e644. https://doi.org/10.1016/j.cmet.2018.06.020

27. Worthmann A, John C, Ruhlemann MC, Baguhl M, Heinsen FA, Schaltenberg N, Heine M, Schlein C, Evangelakos I, Mineo C, Fischer M, Dandri M, Kremoser C, Scheja L, Franke A, Shaul PW, Heeren J (2017) Cold-induced conversion of cholesterol to bile acids in mice shapes the gut microbiome and promotes adaptive thermogenesis. Nat Med 23(7):839-849. https://doi.org/10.1038/ nm.4357 
28. Scheja L, Heeren J (2019) The endocrine function of adipose tissues in health and cardiometabolic disease. Nat Rev Endocrinol 15(9): 507-524. https://doi.org/10.1038/s41574-019-0230-6

29. Solle M, Labasi J, Perregaux DG, Stam E, Petrushova N, Koller BH, Griffiths RJ, Gabel CA (2001) Altered cytokine production in mice lacking P2X(7) receptors. J Biol Chem 276(1):125-132. https://doi.org/10.1074/jbc.M006781200

30. Chessell IP, Hatcher JP, Bountra C, Michel AD, Hughes JP, Green P, Egerton J, Murfin M, Richardson J, Peck WL, Grahames CB, Casula MA, Yiangou Y, Birch R, Anand P, Buell GN (2005) Disruption of the P2X7 purinoceptor gene abolishes chronic inflammatory and neuropathic pain. Pain 114(3):386-396. https:// doi.org/10.1016/j.pain.2005.01.002

31. Masin M, Young C, Lim K, Barnes SJ, Xu XJ, Marschall V, Brutkowski W, Mooney ER, Gorecki DC, Murrell-Lagnado R (2012) Expression, assembly and function of novel C-terminal truncated variants of the mouse $\mathrm{P} 2 \mathrm{X} 7$ receptor: re-evaluation of $\mathrm{P} 2 \mathrm{X} 7$ knockouts. Br J Pharmacol 165(4):978-993. https://doi.org/10. 1111/j.1476-5381.2011.01624.x

32. Di Virgilio F (2007) Liaisons dangereuses: P2X(7) and the inflammasome. Trends Pharmacol Sci 28(9):465-472. https://doi. org/10.1016/j.tips.2007.07.002

33. Martinez-Garcia JJ, Martinez-Banaclocha H, Angosto-Bazarra D, de Torre-Minguela C, Baroja-Mazo A, Alarcon-Vila C, MartinezAlarcon L, Amores-Iniesta J, Martin-Sanchez F, Ercole GA, Martinez CM, Gonzalez-Lisorge A, Fernandez-Pacheco J, Martinez-Gil P, Adriouch S, Koch-Nolte F, Lujan J, AcostaVillegas F, Parrilla P, Garcia-Palenciano C, Pelegrin P (2019) $\mathrm{P} 2 \mathrm{X} 7$ receptor induces mitochondrial failure in monocytes and compromises NLRP3 inflammasome activation during sepsis. Nat Commun 10(1):2711. https://doi.org/10.1038/s41467-019-10626-x

34. Rissiek B, Haag F, Boyer O, Koch-Nolte F, Adriouch S (2015) P2X7 on mouse T cells: one channel, many functions. Front Immunol 6:204. https://doi.org/10.3389/fimmu.2015.00204

35. Surprenant A, North RA (2009) Signaling at purinergic P2X receptors. Annu Rev Physiol 71:333-359. https://doi.org/10.1146/ annurev.physiol.70.113006.100630

36. Koch-Nolte F, Eichhoff A, Pinto-Espinoza C, Schwarz N, Schafer T, Menzel S, Haag F, Demeules M, Gonde H, Adriouch S (2019) Novel biologics targeting the P2X7 ion channel. Curr Opin Pharmacol 47:110-118. https://doi.org/10.1016/j.coph.2019.03. 001

37. Madec S, Rossi C, Chiarugi M, Santini E, Salvati A, Ferrannini E, Solini A (2011) Adipocyte P2X7 receptors expression: a role in modulating inflammatory response in subjects with metabolic syndrome? Atherosclerosis 219(2):552-558. https://doi.org/10.1016/j. atherosclerosis.2011.09.012

38. Pandolfi J, Ferraro A, Lerner M, Serrano JR, Dueck A, Fainboim L, Arruvito L (2015) Purinergic signaling modulates human visceral adipose inflammatory responses: implications in metabolically unhealthy obesity. J Leukoc Biol 97(5):941-949. https://doi.org/10. 1189/jlb.3A1214-626R

39. Sun S, Xia S, Ji Y, Kersten S, Qi L (2012) The ATP-P2X7 signaling axis is dispensable for obesity-associated inflammasome activation in adipose tissue. Diabetes 61(6):1471-1478. https://doi.org/10. 2337/db11-1389

40. Beaucage KL, Xiao A, Pollmann SI, Grol MW, Beach RJ, Holdsworth DW, Sims SM, Darling MR, Dixon SJ (2014) Loss of $\mathrm{P} 2 \mathrm{X} 7$ nucleotide receptor function leads to abnormal fat distribution in mice. Purinergic Signal 10(2):291-304. https://doi.org/ 10.1007/s11302-013-9388-x

41. Zhao H, Bo C, Kang Y, Li H (2017) What else can CD39 tell us? Front Immunol 8:727. https://doi.org/10.3389/fimmu.2017.00727
42. Pandolfi JB, Ferraro AA, Sananez I, Gancedo MC, Baz P, Billordo LA, Fainboim L, Arruvito L (2016) ATP-induced inflammation drives tissue-resident Th17 cells in metabolically unhealthy obesity. J Immunol 196(8):3287-3296. https://doi.org/10.4049/jimmunol. 1502506

43. Enjyoji K, Kotani K, Thukral C, Blumel B, Sun X, Wu Y, Imai M, Friedman D, Csizmadia E, Bleibel W, Kahn BB, Robson SC (2008) Deletion of cd39/entpd1 results in hepatic insulin resistance. Diabetes 57(9):2311-2320. https://doi.org/10.2337/db07-1265

44. Muller G, Schneider M, Biemer-Daub G, Wied S (2011) Upregulation of lipid synthesis in small rat adipocytes by microvesicle-associated CD73 from large adipocytes. Obesity 19(8):1531-1544. https://doi.org/10.1038/oby.2011.29

45. Burghoff S, Flogel U, Bongardt S, Burkart V, Sell H, Tucci S, Ikels K, Eberhard D, Kern M, Kloting N, Eckel J, Schrader J (2013) Deletion of CD73 promotes dyslipidemia and intramyocellular lipid accumulation in muscle of mice. Arch Physiol Biochem 119(2):39 51. https://doi.org/10.3109/13813455.2012.755547

46. Roh HC, Tsai LT, Lyubetskaya A, Tenen D, Kumari M, Rosen ED (2017) Simultaneous transcriptional and epigenomic profiling from specific cell types within heterogeneous tissues in vivo. Cell Rep 18(4):1048-1061. https://doi.org/10.1016/j.celrep.2016.12.087

47. Li W, Wei S, Liu C, Song M, Wu H, Yang Y (2016) Regulation of the osteogenic and adipogenic differentiation of bone marrowderived stromal cells by extracellular uridine triphosphate: the role of P2Y2 receptor and ERK1/2 signaling. Int J Mol Med 37(1):6373. https://doi.org/10.3892/ijmm.2015.2400

48. Young MT, Pelegrin P, Surprenant A (2006) Identification of Thr283 as a key determinant of P2X7 receptor function. Br J Pharmacol 149(3):261-268. https://doi.org/10.1038/sj.bjp. 0706880

49. Tozzi M, Novak I (2017) Purinergic receptors in adipose tissue as potential targets in metabolic disorders. Front Pharmacol 8:878. https://doi.org/10.3389/fphar.2017.00878

50. Giacovazzo G, Apolloni S, Coccurello R (2018) Loss of P2X7 receptor function dampens whole body energy expenditure and fatty acid oxidation. Purinergic Signal 14(3):299-305. https://doi. org/10.1007/s11302-018-9610-y

51. Ussar S, Lee KY, Dankel SN, Boucher J, Haering MF, Kleinridders A, Thomou T, Xue R, Macotela Y, Cypess AM, Tseng YH, Mellgren G, Kahn CR (2014) ASC-1, PAT2, and P2RX5 are cell surface markers for white, beige, and brown adipocytes. Sci Transl Med 6(247):247ra103. https://doi.org/10.1126/scitranslmed. 3008490

52. Razzoli M, Frontini A, Gurney A, Mondini E, Cubuk C, Katz LS, Cero C, Bolan PJ, Dopazo J, Vidal-Puig A, Cinti S, Bartolomucci A (2016) Stress-induced activation of brown adipose tissue prevents obesity in conditions of low adaptive thermogenesis. Mol Metabol 5(1):19-33. https://doi.org/10.1016/j.molmet.2015.10.005

53. Garcia RA, Roemmich JN, Claycombe KJ (2016) Evaluation of markers of beige adipocytes in white adipose tissue of the mouse. Nutr Metabol 13:24. https://doi.org/10.1186/s12986-016-0081-2

54. Arguin G, Bourzac JF, Placet M, Molle CM, Paquette M, Beaudoin JF, Rousseau JA, Lecomte R, Plourde M, Gendron FP (2017) The loss of $\mathrm{P} 2 \mathrm{X} 7$ receptor expression leads to increase intestinal glucose transit and hepatic steatosis. Sci Rep 7(1):12917. https://doi.org/10. 1038/s41598-017-13300-8

Publisher's note Springer Nature remains neutral with regard to jurisdictional claims in published maps and institutional affiliations. 